\title{
1 Influence of soil structure on contaminant leaching from injected
}

\section{2 slurry}

4 M. G. Mostofa Amin ${ }^{\text {a, b, } * \text {, Christina } \emptyset_{\text {sterballe Pedersen }}{ }^{\mathrm{c}} \text {, Anita Forslund }}{ }^{\mathrm{d}, \mathrm{e}}$, Tamie L.

\section{$5 \quad$ Veith $^{\mathrm{f}}$, Mette Laegdsmand ${ }^{\mathrm{a}}$}

6 a Department of Agroecology, Faculty of Science and Technology, Aarhus University,

7 Blichers Alle 20, DK-8830 Tjele, Denmark

$8{ }^{\mathrm{b}}$ Department of Irrigation and Water Management, Bangladesh Agricultural University,

9 Mymensingh 2202, Bangladesh

$10{ }^{\mathrm{c}}$ Danish Technological Institute, Kongsvang Allé 29, DK-8000 Aarhus C, Denmark

$11{ }^{\mathrm{d}}$ Department of Veterinary Disease Biology, University of Copenhagen, 1870 Frederiksberg

12 C, Denmark

13 e National Veterinary Institute, Technical University of Denmark, 1870 Frederiksberg C,

14 Denmark

$15{ }^{\mathrm{f}}$ USDA-ARS, 3702 Curtin Road, University Park, PA 16802, USA

$16 *$ Corresponding author. Email address: mostofa.amin@ bau.edu.bd and

17 aminmgmbau@yahoo.com, Telephone: +8809167401-6 Ext. 2859

\section{ABSTRACT}

21 Animal manure application to agricultural land provides beneficial organic matter and

22 nutrients but can spread harmful contaminants to the environment. Contamination of fresh

23 produce, surface water and shallow groundwater with the manure-borne pollutants can be a

24 critical concern. Leaching and persistence of nitrogen, microorganisms (bacteriophage, $E$. coli, and Enterococcus) and a group of steroid hormone (estrogens) were investigated after 
injection of swine slurry into either intact (structured) or disturbed (homogeneous repacked) soil. The slurry was injected into hexaplicate soil columns at a rate of $50 \mathrm{t} \mathrm{ha}^{-1}$ and followed with four irrigation events: 3.5 -h period at $10 \mathrm{~mm} \mathrm{~h}^{-1}$ after $1,2,3$, and 4 weeks. The disturbed columns delayed the leaching of a conservative tracer and microorganisms in the first irrigation event compared to the intact columns due to the effect of disturbed macropore flow paths. The slurry constituents that ended up in or near the macropore flow paths of the intact soil were presumably washed out relatively quickly in the first event. For the last three events the intact soil leached fewer microorganisms than the disturbed soil due to the bypassing effect of water through the macropore flow path in the intact soil. Estrogen leached from the intact soil in the first event only, but for the disturbed soil it was detected in the leachates of last two events also. Leaching from the later events was attributed to higher colloid transport from the disturbed soils. In contrast, $\mathrm{NO}_{3}-\mathrm{N}$ leaching from the intact soil was higher for all events except the first event, probably due to a lower nitrification rate in the disturbed soil. A week after the last irrigation event, the redistribution of all slurry constituents except $\mathrm{NO}_{3}-\mathrm{N}$ in most of the sections of the soil column was higher for the disturbed soil. Total recovery of E. coli was significantly higher from the disturbed soil and total leaching of mineral nitrogen was significantly lower from the disturbed soil. Results demonstrate how manure-borne constituents injected into undisturbed soil columns respond more as expected in the field, in terms of leaching and persistence, than do the same constituents injected into typically constructed columns of disturbed soil.

Keywords: Contaminants fate; Manure management; Microorganisms; Nitrogen; Estrogen; Repacked column 


\section{1. Introduction}

52 Soil amendment with animal slurry, a mixture of urine, feces and water, is an economical and viable option for replenishing nutrients and organic matter in cropped soils (Hjorth et al., 2010). It is also a sustaining option for recycling nutrients at the farm level. Application of animal slurry into soil, however, can potentially introduce harmful slurry-borne contaminants into the environment (Lee et al., 2007). The contaminants of land-applied slurry may take different pathways to groundwater and/or surface water bodies via direct runoff, subsurface flow, leaching and percolation depending on the local hydrology (Bech et al., 2014; Kjaer et al., 2007). Inappropriate handling of manure can cause nitrate pollution to groundwater (Mantovi et al., 2006), eutrophication to surface water (Norring and Jorgensen, 2009), pathogenic contamination of ready-to-eat type crops and untreated water facilities (Franz and van Bruggen, 2008), and aquatic ecology degradation by organic pollutants like steroid hormones (Sumpter and Johnson, 2008).

Identifying the best management practices in relation to animal slurry application to agricultural fields has become very important in the effort to reduce nutrient loading to the stream, contamination of the surrounding environment, and nuisance odor (Hjorth et al., 2010; Lee et al., 2007). Reduced tillage or no-till agriculture has been increasingly practiced worldwide as a soil and water conservation practice. No-till practice reduces the opportunity of incorporation of surface-applied manure with soil, which can augment the runoff loss of nutrient and manure-borne contaminants. Slurry injection on no-till agricultural land is therefore a slurry management technique recognized as a best management practice (Dell et al., 2012). It is important to know whether soil structural condition, disturbed or nondisturbed, prior to slurry injection makes any difference in the leaching and transport susceptibility of different manure-born constituents. 
77 Both intact (non-disturbed monolith-type) and disturbed soil (repacked columns) have been used to study transport of contaminants in soil (Das et al., 2004; Lucas and Jones, 2009).

Both methods have some advantages and disadvantages as reviewed by Lewis and Sjöstorm (2010). Disturbed soil is more homogeneous than intact soil. Macropore structure generated through weathering and biogeochemical activities is generally destroyed during the repacking process, altering the transport paths of water, solutes, and suspended colloids (Lewis and Sjöstorm, 2010). Structural changes in the soil can crucially influence the filtering functions that reduce direct groundwater contamination (Robinson et al., 2012). Flow through macropores exerts non-equilibrium solute transport that shifts the sorption/attachment or retardation of contaminants, and, thereby, reduces the filtering effect of the soil and the time available for degradation (Jarvis, 2007; Laegdsmand et al., 2009). Presence of macropore flow under field conditions has been identified to augment manure-borne estrogen transport (Kjær et al., 2007; Laegdsmand et al., 2009). Macropore flows are also known to influence the leaching of microorganisms (Safadoust et al., 2011).

91

Understanding how the environmental fate of a range of slurry-borne contaminants responds to a change in soil structure is important for soil and manure management options. A leaching experiment using both intact and disturbed soil can show the comparative effects on the environmental fate of different slurry-borne constituents. Soil sampled from a plough layer represents the critical zone of contaminant transport under field conditions because this part of the soil is the most biologically, physically and chemically active. The objective of this study was to determine if disturbing field soil structure, when constructing laboratory soil columns, significantly impacted leaching patterns of common pig slurry constituents. To this 
101 for intact and disturbed soil columns of commonly found contaminants in pig slurry: total organic carbon (TOC), mineral nitrogen (N), Salmonella enterica serovar Typhimurium bacteriophage 28B (phage) as a representative organism for viruses, Escherichia coli (E. coli) and Enterococcus spp. as representative organisms for pathogenic bacteria, and the summation of three types of estrogen (estrone, 17 $\alpha$-estradiol and 17 $\beta$-estradiol) to represent steroid hormones.

107

\section{2. Materials and methods}

\subsection{Soil and slurry}

110 The study location was at Foulum Experimental Station $\left(56^{\circ} 29^{\prime} \mathrm{N}, 9^{\circ} 34^{\prime} \mathrm{E}\right)$, Denmark.

111 Fifteen intact soil columns, 20-cm long and 20-cm diameter, were collected from a crop field

112 in a spring barley-winter wheat-spring barley rotation, as described previously in Amin et al.

113 (2013). Soil at location is a Typic Hapludult loamy sand with a visible humic A-horizon, 114 influenced by tillage and ranging as deep as $44 \mathrm{~cm}$. Three repacked columns were prepared 115 using soil from a single field and maintaining a consistent bulk density. Soil moisture content

116 during repacking was at field capacity, and repacking was in accordance with the general 117 guidelines of soil column preparation (Lewis and Sjostrom, 2010). All soil columns were 118 saturated slowly and then drained to a soil water content (SWC) potential of $-100 \mathrm{hPa}$ (i.e., 119 field capacity) to achieve uniform soil moisture.

121 To allow greater application under phosphorus-restricted nutrient management practices, the

122 phosphorous-rich solid part of the raw animal slurry is usually separated out before land 123 application (Hjorth et al., 2010; Liu et al., 2016). Thus, only the liquid fraction of

124 mechanically separated swine slurry was collected from a farm near Åbøl, Denmark and stored at $2^{\circ} \mathrm{C}$ until applied to the soil columns. E. coli and Enterococcus spp. in the slurry 
126 acted as model organisms for bacteria. The slurry was spiked with $1.5 \times 10^{6} \mathrm{PFU} \mathrm{mL} \mathrm{m}^{-1}$ of

127 phage and $2 \mathrm{~g} \mathrm{~L}^{-1}$ of 2,6-difluorobenzoic acid (FBA; CAS RN 385-00-2; Sigma-Aldrich,

128 Germany) before soil application to provide a model organism for pathogenic viruses and a

129 nonreactive tracer, respectively. No significant toxicity effect of FBA on the microorganisms

130 studied was found in a toxicity test before starting the main experiment, which agreed with

131 the findings of McCarthy et al. (2000).

132

\subsection{Experiment procedure}

134 The experiment was conducted in a climate-controlled room at $10^{\circ} \mathrm{C}$. Each soil column was 135 placed on a glass filter disc of $60-100 \mu \mathrm{m}$ pore size and $1.6 \mathrm{~cm}$ thickness (ROBU,

136 Glassfiltergerate GMBH, Germany), on top of a stainless steel plate (Fig. 1). Suction of -12.5

$137 \mathrm{hPa}$ was maintained on each soil column's lower boundary by a water-filled space between

138 the glass filter disc and stainless steel plate and by a hanging water column in a hypodermic

139 needle attached to the stainless steel plate (Fig. 1) (Laegdsmand et al., 2005). The filtering

140 effect due to the combination of filter disc, steel plate and hypodermic needle was tested, and

141 the differences in contaminant concentrations entering and leaving the below-column setup

142 were insignificant.

144 The mechanically separated liquid slurry fraction was added to hexaplicate intact and

145 triplicate disturbed soil (repacked) columns by subsurface injection at a rate of $50 \mathrm{t} \mathrm{ha}^{-1}$ (145

$146 \mathrm{~kg} \mathrm{ha}^{-1}$ mineral $\mathrm{N}$ and $215 \mathrm{~kg} \mathrm{ha}^{-1}$ total $\mathrm{N}$ ) as described by Amin et al. (2013). A slit was

147 created at the center of the column surface to inject the slurry and then backfilled with soil

148 loosely after slurry application, resulting in an injection shape, depth, and closure similar to a

149 shallow-disk field coulter (Fig. 1). A rainfall simulator was calibrated to apply artificial

150 rainwater $\left(0.1 \mathrm{mM} \mathrm{NaCl}, 0.01 \mathrm{mM} \mathrm{CaCl}_{2}\left(2 \mathrm{H}_{2} \mathrm{O}\right)\right.$, and $0.01 \mathrm{mM} \mathrm{MgCl} \mathrm{Mg}_{2}\left(6 \mathrm{H}_{2} \mathrm{O}\right)$; supplied by 
151 VWR, Denmark) to the columns at a uniform intensity of $10 \mathrm{~mm} \mathrm{~h}^{-1}$ (Laegdsmand et al., 152 2009). Four 3.5-h long separate irrigation events were applied to each of the slurry injected

153 columns 1, 2, 3 and 4 weeks after slurry application. Triplicate soil columns without slurry

154 injection, as control, were also exposed to similar irrigation events. The control columns were

155 undisturbed to study the background concentration of contaminants. We used acid-washed

156 and sterilized equipment to avoid any contamination during experiment period.

158 Leachates were collected in sterilized blue cap laboratory glass bottles until percolation from 159 each irrigation event had ended. Subsamples of leachates of the first irrigation event were 160 collected at 15, 30, 60, 120, 180, $240 \mathrm{~min}$ for tracer breakthrough analysis. One week after 161 the final (the fourth) irrigation event, soil columns were slowly pressed out from the stainless steel casing and sectioned into four subsamples — the original slurry hotspot (S1) and three other subsamples (S2, S3 and S4) (Fig. 1). All samples were prepared immediately after

164 collection and analyzed for the selected contaminants within 24 hours.

\subsection{Analytical methods}

167 The gravimetric SWC was determined by drying $\left(105^{\circ} \mathrm{C}\right.$ for $\left.24 \mathrm{~h}\right)$, and volatile solids (VS) 168 content by combustion of dried soil at $550^{\circ} \mathrm{C}$ for three hours (Broadbent, 1965). A Sentron $1693001 \mathrm{pH}-$ meter (Roden, The Netherlands) was used for $\mathrm{pH}$ and a Radiometer conductivity170 meter (Copenhagen, Denmark) for electrical conductivity (EC) measurement for both soil samples and leachates. A HACH 2100 AN turbidimeter (Hach, Loreland, CO) equipped with an EPA filter measuring at wavelengths $400-600 \mathrm{~nm}$ measured turbidity in the leachates.

173 Concentration of TOC in the leachates was measured on a total organic carbon analyzer

174 (TOC- $\mathrm{V}_{\mathrm{CPH}}$, Shimadzu, Duisburg, Germany). The leachates were analyzed for FBA

175 concentrations by a LC-MS/MS technique following the method of Juhler and Mortensen 
176 (2002). Both $\mathrm{NH}_{4}-\mathrm{N}$ and $\mathrm{NO}_{3}-\mathrm{N}$ concentration in soil extracts and leachates were analyzed on

177 an Auto-analyzer III Digital Colorimeter (Bran \& Luebbe, Germany). Soil subsamples extracted in $1 \mathrm{M} \mathrm{KCl}$ were filtered (GA55; Advantec, Japan) for this analysis.

180 A double-agar layer method (Adams, 1959) was followed for phage enumeration. The host 181 strain Salmonella enterica serovar Typhimurium Type 5 was grown in Nutrient Broth 182 (Oxoid) at $37^{\circ} \mathrm{C}$ for 4 hours. Next, two grams of soil were added to $18 \mathrm{~mL}$ Maximum Recovery Diluent (MRD, Oxoid) and sonicated for 30 s. One mL 10-fold diluted sample was mixed with $1 \mathrm{~mL}$ broth culture of the host strain and $3 \mathrm{~mL}$ soft agar, a mixture of $70 \%$ Blood agar base (Oxoid) and 30\% Nutrient Broth (Oxoid). The mixture was spread on a well-dried Blood agar base plate (Oxoid) and incubated at $37^{\circ} \mathrm{C}$ for $18 \mathrm{~h}$. Clear zones were counted as plaques forming units (PFUs). The error associated with the method is $\pm 20 \%$ (Chu et al., leachates.

Viable E. coli in each soil section and leachates were determined on E. coli Petrifilms (3M $\mathrm{a} / \mathrm{s}$, Denmark). Two grams of soil were mixed with $18 \mathrm{~mL}$ of $0.01 \mathrm{M}$ phosphate buffer in a glass tube followed by sonication for $20 \mathrm{~s}$ (Vail et al., 2003). Ten-fold diluted soil and leachate samples were plated in triplicate and then incubated at $37^{\circ} \mathrm{C}$ for 24 hours.

195 Characteristic blue colonies were counted as E. coli (CFU). The detection limit for E. coli was $10 \mathrm{CFU} \mathrm{g}^{-1}$ for soil and $1 \mathrm{CFU} \mathrm{mL}^{-1}$ for leachates.

198 Both soil and leachate samples were diluted in MRD as described for phage dilution. One $\mathrm{mL}$ 199 diluted sample was spread on Slanetz and Bartley Medium (Oxoid, Denmark). The number of 200 Enterococcus spp. was determined as typical red-maroon colonies on the Slanetz and Bartley 
Medium following incubation at $44^{\circ} \mathrm{C}$ for $48 \pm 4 \mathrm{~h}$ (DS 2401, 1999). The detection limit for

concentrations of microorganisms were determined from triplicate diluted samples, average concentrations reported can be less than $10 \mathrm{CFU} / \mathrm{PFU} \mathrm{g}{ }^{-1}$ soil or $1 \mathrm{CFU} / \mathrm{PFU} \mathrm{mL} \mathrm{m}^{-1}$ leachate.

Estrogens (estrone, $17 \alpha$-estradiol and $17 \beta$-estradiol) in water samples were measured by a GC-MS/MS technique. Water samples were treated according to Laegdsmand et al. (2009) before analysis. Analysis was performed on a GC (CP-3800 GC, Varian), coupled to an ion trap MS (Saturn 2000, Varian). The GC was fitted with a DB-5MS column $(30 \mathrm{~m} \times 0.25 \mathrm{~mm}$

$210 \times 0.25 \mu \mathrm{m}$, Agilent Technologies, Denmark) and temperature programmed as in Laegdsmand

211 et al. (2009). Analytes were ionized by electron ionization (70 eV) and non-resonant collision induced dissociation was applied for further fragmentation of selected precursor ions.

\subsection{Statistical analysis}

215 The statistical software R was used for statistical analyses (R Development Core Team, 2009).

216 Analysis of variance (ANOVA) of the data was conducted at the $95 \%$ confidence level to evaluate differences in leaching of the contaminants between treatments.

\section{Results and discussion}

\subsection{Leachates and soils}

Physicochemical properties of soil and slurry are shown in Table 1 . The initial $\mathrm{N}$ content in concentrations of the constituents in slurry (total $\mathrm{N} 4.3 \mathrm{~g} \mathrm{~kg}^{-1}$, total solids $3.14 \%$, VS $1.97 \%$, E. coli $2.6 \times 10^{4} \mathrm{CFU} \mathrm{mL}{ }^{-1}$, and Enterococcus sp. $3.2 \times 10^{4} \mathrm{CFU} \mathrm{mL}^{-1}$ ) were high enough to act as model indicators for this leaching study. 
227 One week after the final irrigation event, SWC in all sections except S3 of the disturbed soil

228 (repacked columns) was significantly greater than those of the intact columns (Fig. 2).

229 Mixing and disturbance of soil aggregates presumably increased water holding capacity by

230 decreasing both the number of larger macropores and very fine micropores and increasing the

231 number of capillary pores (Schjonning et al., 1998). It also increased matrix flow by reducing

232 any possible preferential flow path. The disturbed soil had higher $\mathrm{pH}$ in all sections than did

233 the intact soil, probably due to the effect of the higher redistribution of slurry constituents in

234 disturbed soil by the end of the final irrigation event (Fig. 2). Correspondingly, leachate $\mathrm{pH}$

235 from the disturbed soil columns was consistently less than from the intact soil throughout the

236 experiment, but increased steadily from the first through the fourth irrigation events while

237 electrical conductivity decreased steadily (Fig. 3).

238

239 Soil section S1 (the slurry-applied slit), in both the intact and disturbed columns, maintained

240 a higher SWC than the other sections one week after the last irrigation event, whereas SWC

241 was similar in soil sections S2-S4 of all treatments (Fig. 2). The organic matter of slurry

242 retained in S1 possibly increased the residual SWC as described by other studies (Amin et al.,

243 2014; Petersen et al., 2003). Volatile solids content can be used as an indicator of organic

244 matter. Values of VS, pH, and EC were greater in S1 for both column types as a result of the

245 effect of residual slurry constituents.

247 3.2. Non-reactive tracer and total organic carbon (TOC)

248 The breakthrough curves of the tracer from two soil structures differed (Fig. 3). For the intact

249 soil, the highest concentration of FBA in leachate was found in the $1^{\text {st }}$ irrigation event; after

250 the $2^{\text {nd }}$ irrigation event the amount of FBA leached decreased linearly. In contrast, the

251 leachate concentration of the tracer for the disturbed soil was much lower in the $1^{\text {st }}$ event, 
252 peaked in the $2^{\text {nd }}$ event, and then started to decrease steadily. The difference in the $1^{\text {st }}$ event was attributed to the macropore flow pattern in the intact soil, which was largely non-existent in the disturbed soil. Macropore flow, often observed in intact soils, is a mechanism leading to preferential flow, and it is reflected in the early arrival of tracer. The disturbed soil produced higher leaching of FBA in $2^{\text {nd }}$ through $4^{\text {th }}$ irrigation events than the intact soil.

The leaching pattern of TOC was similar to that of the nonreactive tracer. The hydrophilic parts of organic matter are transported in solution as a non-reactive tracer. However, the hydrophobic constituents of organic matter could be attached to soil particles (Dunnivant et al., 1992), explaining why the difference in TOC leachate between the two column types during the $2^{\text {th }}-4^{\text {th }}$ irrigation events was smaller than the difference in non-reactive tracer FBA (Fig. 3). Although the leaching patterns for the two soil column types were somewhat different, the total amount of TOC leached over the four irrigation events from each was similar, $216 \pm 13$ and $217 \pm 25 \mathrm{mg}$ for intact and disturbed soil, respectively.

\subsection{Mineral nitrogen $(N)$}

Total mineral $\mathrm{N}$ leached from the disturbed columns was lower than that of the intact

columns during the experimental events and percentage retained in the disturbed columns was higher, but the total recovery was similar (Table 2). Pradoa et al. (2011) conducted a nitrate fate study using both intact and disturbed soil and found that water bypassed $27 \%$ of pore space in intact column because of preferential flow pathways. They observed that nitrate fate in the soil profile was affected by preferential flow in intact soil. This process increased the $\mathrm{NO}_{3}-\mathrm{N}$ mobility, thus reducing the resident solute time and increasing the risk for groundwater contamination. 
277 Due to matrix-flow dominated conditions in the disturbed soil, $\mathrm{NH}_{4}-\mathrm{N}$ came into contact with 278 more sorption sites than in the intact soil (Abdulgawad et al., 2008). Accordingly, sections $279 \mathrm{~S} 1-\mathrm{S} 3$ of the disturbed columns retained more $\mathrm{NH}_{4}-\mathrm{N}$ a week after the final irrigation event 280 than those of the intact columns (Fig. 2). Also, in the first three irrigation events, the 281 disturbed columns released less $\mathrm{NH}_{4}-\mathrm{N}$ than the intact columns (Fig. 3).

The leaching pattern of $\mathrm{NO}_{3}-\mathrm{N}$ was markedly different for the two soil conditions. Leaching of $\mathrm{NO}_{3}-\mathrm{N}$ decreased from the first through the third irrigation events for the disturbed soil while it increased linearly for the intact soil (Fig. 3). Leaching of $\mathrm{NO}_{3}-\mathrm{N}$ from the disturbed soil in the $1^{\text {st }}$ irrigation event was even higher than that of the intact soil. The nitrification rate in the disturbed soil during the time between slurry injection and the $1^{\text {st }}$ irrigation event was probably higher, allowing $\mathrm{NO}_{3}-\mathrm{N}$, the more mobile form of mineral $\mathrm{N}$, to accumulate sufficiently for leaching in the first irrigation event. This higher initial nitrification before the irrigation event in the disturbed soil can be attributed to the higher initial redistribution of slurry in soil (Petersen et al., 2003) and soil aeration during repacking. After the $1^{\text {st }}$ irrigation event, SWC was comparatively higher in the disturbed soil as discussed earlier, which could reduce nitrification after the $1^{\text {st }}$ irrigation event and reduce $\mathrm{NO}_{3}-\mathrm{N}$ leaching from $2^{\text {nd }}$ irrigation event.

\subsection{Microorganisms}

297 Leaching of microorganisms as affected at the temporal scale by the soil structures was

298 similar for all species studied (Fig. 3). In the $1^{\text {st }}$ irrigation event, microorganisms leached 299 from the disturbed soil were either equal (bacteria) or lower (phage) than those from the 300 intact soil, but for the rest of the irrigation events the disturbed soil resulted in higher 301 leaching (Fig. 3). This trend was also shown by the non-reactive tracer and TOC. However, 
these differences were not significant for Enterococcus spp. In addition to the effects of soil structure, microorganism leaching generally decreases with time because of its natural die-

off. These results are in general agreement with other findings of microbial transport

(Mawdsley et al., 1995). Safadoust et al. (2012) reported that earlier peaks in the breakthrough curves of $E$. coli were observed for weathered soil columns compared to those

307 for disturbed soil.

Although the temporal leaching pattern of phage and E. coli differed across the two soil conditions, no significant difference in total leached amount was observed for any microorganism (Table 2). Total retention and recovery for the two soil conditions were also similar except for E. coli (Table 2). E. coli retained, and recovered, in soil after the final irrigation event was significantly higher in the disturbed columns compared to the intact

314 columns.

316 Concentrations of E. coli across the four soil sections were higher in the disturbed soil

317 compared to the intact soil (Fig. 2), suggesting that the redistribution and/or survival of $E$.

318 coli was higher in the disturbed soil. Relatively higher SWC and medium pore size in the 319 disturbed soil presumably helped E. coli survive longer, facilitating higher leaching of viable

$320 E$. coli in $2^{\text {nd }}-4^{\text {th }}$ irrigation events. Redistribution levels and survival rates of $E$. coli were 321 proportional, as observed by other studies (Amin et al., 2014). Better redistribution of E. coli 322 towards relatively smaller pores in the disturbed soil may have provided physical protection against predation (Kim and Corapcioglu, 2002; Vargas and Hattori, 1986). In contrast, the concentrations of phage and Enterococcus spp. in different soil sections were not affected by the soil structures (Fig. 2). 
The redistribution of phage was higher due to its smaller size compared to bacteria.

Enterococcus spp. was not detected in S4 of the disturbed columns and was detected at very

low concentrations in S4 of the intact columns while the concentrations in $\mathrm{S} 1$ were still much

higher (1000 CFU g ${ }^{-1}$ ) for both soil conditions (Fig. 2), suggesting a slow transport of these bacteria. Enterococcus spp. cells are smaller than E. coli, but the chain organization of cells may have caused lower mobility in soil (Kokkinos et al., 1998; Pachepsky et al., 2006).

\subsection{Estrogen}

Estrogen was detected in leachates of the intact columns in the $1^{\text {st }}$ irrigation event only, but it leached during the last two events also for the disturbed columns (Fig. 3). Estrogen sorption to slurry organic matter is very high (Lucas and Jones, 2009). Sorption of estrogen to any sorbent material increases with its TOC content. The solid-liquid partition coefficients of estrogen with slurry particles were 10 to 30 times higher than those of soils (Amin et al., 2012), so any release of estrogens from the slurry slit (S1) to the surrounding soil was possibly very low. When some estrogen released with the liquid phase of the slurry, its movement in soil was retarded because it readily sorbs to the soil particles (Das et al., 2004).

343 Estrogen also degrades quickly in soil (Lee et al., 2007). However, colloid-mediated as well as preferential flow-facilitated transport of estrogen up to one meter soil depth is reported in literature (Kjær et al., 2007; Laegdsmand et al., 2009). The detection of estrogen in the last two irrigation events of the disturbed soil was attributed to the slurry-colloid mediated transport. The turbidity data of the disturbed soil supports this argument. de Jonge et al.

348 (2004) suggested that colloids that are mobilized (dispersed) and stable in suspension are able to carry strongly bound contaminants downward and can increase the contamination of soil and groundwater. 


\subsection{Implications and limitations}

353 Pattern differences in leaching of the nonreactive tracer between the disturbed and intact soil

354 during the first irrigation event, as also supported by the leaching patterns of phage and TOC, 355 suggest that there were influences of preferential flow paths in the intact soil columns. Slurry 356 constituents/ contaminants that ended up close to and/or in the preferential flow path were

357 transported with infiltrating water relatively quickly in the $1^{\text {st }}$ irrigation event. The remaining slurry constituents in the soil matrix received less interaction with infiltrated water because some of water bypassed via the preferential flow path. In the homogeneous disturbed soil, slurry constituents interacted more with infiltrated water in the matrix-flow dominated condition. Leaching of all contaminants/ microorganisms except mineral nitrogen during $2^{\text {nd }}$ $-4^{\text {th }}$ irrigation events was thus higher for the disturbed columns compared to the intact columns.

Preferential flow phenomena were apparently not dominant in this study because clay content (8\%) was low. In structured soil with high clay content, preferential flow can have pronounced effect on the transport of contaminants (Horn, 1990; Jarvis, 2007). The method of introducing contaminants to the soil environment may interact with soil structure to influence leaching pattern and persistence, e.g. contaminants with surface applied versus injected slurry (Forslund et al., 2011) and application on ploughed versus no-till soils (Saini et al., 2003). In this study, contaminants in a single-injection slurry scenario were studied, but the effect of soil structure would be more pronounced in a scenario for which contaminants were introduced over multiple irrigation events (i.e., Safadoust et al., 2011). In the latter scenario contaminants can bypass the majority of the soil by moving through the active macropore flow path in each event. More tortuous, finer pores within soil aggregates in the 
bulk portion of the soil can slow down the water and chemical transport as well as retard the chemical exchange processes (Horn, 1990).

\section{Conclusions}

Changes in soil structure before manure injection significantly impacted the leaching pattern of slurry-borne contaminants/constituents. Particularly for biologically and chemically active manure-borne compounds, disturbing the soil adversely influenced the results as compared to the expected field response, which was represented by the intact soil columns. The findings should be considered when drawing conclusions from leaching experiments with only disturbed columns. These findings will be useful in assessing the manure, tillage and soil management practices for mitigation and regulatory strategies relative to nutrient loss reduction and fecal bacteria contamination of soil and water. Similar studies with different textured soils and different methods of introducing contaminants to the soil environment broaden the applicability of the knowledge gained by this study.

\section{Acknowledgements}

This study was supported by the Pathos Project funded by the Strategic Research Council of Denmark (ENV 2104-07-0015) and Grundfoss New Business A/S. We appreciate the technical assistance of R. K. Juhler from GEUS, Copenhagen and Maibritt Hjorth, Michael Koppelgaard, Stig Rasmussen, and Palle Jorgensen from Faculty of Science and Technology of Aarhus University, Denmark. Mention of trade names or commercial products in this publication is solely for the purpose of providing specific information and does not imply recommendation or endorsement by the U.S. Department of Agriculture. USDA is an equal opportunity provider and employer. 


\section{References}

402

403

404

405

406

407

408

409

410

411

412

413

414

415

416

417

418

419

420

421

422

Abdulgawad, F., Bockelmann, E.B., Sapsford, D., Williams, K.P., Falconer, R., 2008. Ammonium ion adsorption on clays and sand under freshwater and seawater conditions. Proceedings of 16th IAHR-APD Congress and 3rd Symposium of IAHR-ISHS. October 20-23 2008, Hohai University, Nanjing, China.

Adams, M.H., 1959. Bacteriophages. New York: Interscience Publishers.

Amin, M.G.M., Petersen, S.O., Lægdsmand, M., 2012. Sorption of 17ß-estradiol to pig slurry separates and soil in soil-slurry environment. J. Environ. Qual. 41, 179-187.

Amin, M.G.M., Forslund, A., Bui, X.Z., Juhler, R.K., Petersen, S.O., Laegdsmand, M., 2013. Persistence and leaching potential of microorganisms and mineral $\mathrm{N}$ in animal manure applied to intact soil columns. Appl. Environ. Microbiol. 79(2), 535-542.

Amin, M.G.M., Bech, T.B., Forslund, A., Hansen, M., Petersen, S.O., Laegdsmand, M., 2014. Redistribution and persistence of microorganisms and steroid hormones after soilinjection of swine slurry. Sci. Total Environ. 466-467, 1003-1010.

Bech, T.B., Rosenbom, A.E., Kjaer, J., Amin, M.G.M., Olsen, P., Jacobsen, C.S., 2014. Factors influencing the survival and leaching of tetracycline-resistant bacteria and Escherichia coli through structured agricultural fields. Agric. Ecosyst. Environ. 195, $10-17$.

Broadbent, F.E., 1965. Organic matter. In C.A. Black et al. (Ed.), Methods of soil analysis, Madison, WI: Part 2, 1st ed. Agron. Monogr. 9. ASA. pp. 1397-1400.

Chu, Y., Jin, Y., Flury, M., Yates, M.V., 2001. Mechanisms of virus removal during transport in unsaturated porous media. Water Resour. Res. 37, 253-263. 
Das, B.S., Lee, L.S., Rao, P.S.C., Hultgren, R.P., 2004. Sorption and degradation of steroid hormones in soils during transport: Column studies and model evaluation. Environ. Sci. Technol. 38, 1460-1470.

Dell, C.J., Kleinman, P.J.A., Schmidt, J.P., Beegle, D.B., 2012. Low-disturbance manure incorporation effects on ammonia and nitrate loss. J. Environ. Qual. 41, 928-937.

de Jonge, L.W., Kjaergaard, C., Moldrup, P., 2004. Colloids and colloid facilitated transport of contaminants in soils: An introduction. Vadose Zone J. 3, 321-325. doi:10.2136/vzj2004.0321

Dunnivant, F.M., Jardine, P.M., Taylor, D.L., McCarthy, J.F., 1992. Transport of naturallyoccurring dissolved organic-carbon in laboratory columns containing aquifer material. Soil Sci. Soc. Ame. J. 56, 437-444.

DS 2401, 1999. Environmental quality-Enumeration of enterococci-Colony count on solid medium-Spread plate method. Danish Standard.

Forslund, A., Markussen, B., Toenner-Klank, L., Bech, T.B., Jacobsen, O.S., Dalsgaard, A., 2011. Leaching of Cryptosporidium parvum oocysts, Escherichia coli and a Salmonella enterica serovar Typhimurium bacteriophage through intact soil cores following surface application and injection of slurry. Appl. Environ. Microbiol. 77, 8129-8138.

Franz, E., Van Bruggen, A.H.C., 2008. Ecology of E. coli O157:H7 and Salmonella enterica in the primary vegetable production chain. Crit. Rev. Microbiol. 34, 143-161.

Hjorth, M., Christensen, K.V., Christensen, M.L., Sommer, S.G., 2010. Solid-liquid separation of animal slurry in theory and practice. A review. Agron. Sustain. Develop. $30,153-180$. 
Horn, R., 1990. Aggregate characterization as compared to soil bulk properties. Soil Tillage Res. 17, 265-289.

Jarvis, N.J., 2007. A review of non-equilibrium water flow and solute transport in soil macropores: Principles, controlling factors and consequences for water quality. Eur. J. Soil Sci. 58, 523-546. doi:10.1111/j.1365-2389.2007.00915.x

Juhler, R.K., Mortensen, A.P., 2002. Analysing fluorobenzoate tracers in groundwater samples using liquid chromatography-tandem mass spectrometry - A tool for leaching studies and hydrology. J. Chromatogr. A 957, 11-16.

Kim, S.B., Corapcioglu, M.Y., 2002. Contaminant transport in dualporosity media with dissolved organic matter and bacteria present as mobile colloids. J. Contam. Hydrol. 59, $267-289$.

Kjaer, J., Olsen, P., Bach, K., Barlebo, H.C., Ingerslev, F., Hansen, M., Halling-Sorensen, B., 2007. Leaching of estrogenic hormones from manure-treated structured soils. Environ. Sci. Technol. 41, 3911-3917.

Kokkinos, A., Fasseas, C., Eliopoulos, E., Kalantzopoulos, G., 1998. Cell size of various lactic acid bacteria as determined by scanning electron microscope and image analysis. Lait 78, 491-500.

Laegdsmand, M., Andersen, H., Jacobsen, O.H., Halling-Sørensen, B., 2009. Transport and fate of steroid estrogens in slurry-amended soil monoliths. J. Environ. Qual. 38, 955964.

Laegdsmand, M., de Jonge, L.W., Moldrup, P., 2005. Leaching of colloids and dissolved organic matter from columns packed with natural soil aggregates. Soil Sci. 170, 13-27. 
Lee, L.S., Carmosini, N., Sassman, S.A., Dion, H.M., Sepulveda, M.S., 2007. Agricultural contributions of antimicrobials and hormones on soil and water quality. Adv. Agron. 93,

469 $1-68$.

470

471

472

473

474

475

476

477

478

479

480

481

482

483

484

485

486

487

488

Lewis, J., Sjostrom, J., 2010. Optimizing the experimental design of soil columns in saturated and unsaturated transport experiments. J. Contamin. Hydrol. 115, 1-13.

Liu, Z., Carroll, Z.S., Long, S.C., Gunasekaran, S., Runge, T., 2016. Use of cationic polymers to reduce pathogen levels during dairy manure separation. J. Environ. Manage. 166, 260-266.

Lucas, S.D., Jones, D.L., 2009. Urine enhances the leaching and persistence of estrogens in soils. Soil Biol. Biochem. 41, 236-242.

Mawdsley, J.L., Bardgett, R.D., Merry, R.J., Pain, B.F., Theodorou, M.K., 1995. Pathogens in livestock waste, their potential for movement through soil and environmental pollution. Appl. Soil Ecol. 2,1-15.

Mantovi, P., Fumagalli, L., Beretta, G.P., Guermandi, M., 2006. Nitrate leaching through the unsaturated zone following pig slurry applications. J. Hydrol. 316, 195-212.

McCarthy, J.F., Howard, K.M., Mckay, L.D., 2000. Effect of pH on sorption and transport of fluorobenzoic acid ground water tracers. J. Environ. Qual. 29, 1806-1813.

Norring, N.P., Jorgensen, E., 2009. Eutrophication and agriculture in Denmark: 20 years of experience and prospects for the future. Hydrobiologia 629, 65-70.

Pachepsky, Y.A., Sadeghi, A.M., Bradford, S.A., Shelton, D.R., Guber, A.K., Dao, T., 2006. Transport and fate of manure-borne pathogens: modeling perspective. Agric. Water Manage. 86, 81-92. 
Petersen, S.O., Nissen, H.H., Lund, I., Ambus, P., 2003. Redistribution of slurry components as influenced by injection method, soil, and slurry properties. J. Environ. Qual. 32, 2399-2409.

Pradoa, B., Duwigb, C., Etcheversc, J., Gaudetd, J.P., Vaucline, M., 2011. Nitrate fate in a Mexican Andosol: Is it affected by preferential flow? Agric. Water Manage. 98, 14411450.

R Development Core Team, 2009. R: A language and environment for statistical computing. R Foundation for Statistical Computing, Vienna, Austria. Available at http://www.Rproject.org (accessed May 2015).

Robinson, D.A., Hockley, N., Dominati, E., Lebron, I., Scow, K.M., Reynolds, B., Emmetta, B.A., Keithe, A.M., de Jonge L.W., Schjønningg, P., Moldrupg, P., Jonesh, S.B., Tulleri, M., 2012. Natural capital, ecosystem services, and soil change: Why soil science must embrace an ecosystems approach. Vadose Zone J. 11, 1. doi:10.2136/vzj2011.0051

Safadoust, A., Mahboubi, A.A., Gharabaghi, B., Mosaddeghi, M.R., Voroney, P., Unc, A., Sayyad, Gh., 2011. Bacterial filtration rates in repacked and weathered soil columns. Geoderma 167-168, 204-213.

Safadoust, A., Mahboubi, A.A., Mosaddeghi, M.R., Gharabaghi, B., Unc, A., Voroney, P., Heydari, A., 2012. Effect of regenerated soil structure on unsaturated transport of Escherichia coli and bromide. J. Hydrol. 430-431, 80-90.

Saini, R., Halverson, L.J., Lorimor, J.C., 2003. Rainfall timing and frequency influence on leaching of Escherichia coli $\mathrm{RS} 2 \mathrm{G}$ through soil following manure application. J. Environ. Qual. 32, 1865-1872. 
511 Schjonning, P., Thomson, I.K., Christensen, B.T., 1998. Soil porosity as a habitat for microorganisms. In: Borrensen, T. (ed.). Proceeding of NJF-seminar No. 286: Soil tillage and biology, Agricultural University of Norway, 8-10 June 1998, NJFUTREDNING/RAPPORT nr. 124, 49-56.

515 Sumpter, J.P., Johnson, A.C., 2008. 10th anniversary perspective: Reflections on endocrine 516 disruption in the aquatic environment: from known knowns to unknown unknowns (and many things in between). J. Environ. Monit. 10, 1476-1485. of waterborne Escherichia coli with petrifilm plates: Comparison to standard methods. J. Environ. Qual. 32, 368-373. Microbiol. Lett. 38, 233-242. 
536 Table 1

537 Selected physicochemical properties of soil and animal slurry used.

\begin{tabular}{|c|c|c|}
\hline Properties & Soil & Slurry \\
\hline Bulk density/ density $\left(\mathrm{g} \mathrm{cm}^{-3}\right)$ & 1.53 & 1.01 \\
\hline Porosity (\%) & 41 & $\mathrm{NA}^{\mathrm{a}}$ \\
\hline Texture: clay, silt, sand (\%) & $8,13,79$ & NA \\
\hline $\mathrm{EC}^{\mathrm{a}}\left(\mathrm{mS} \mathrm{cm}^{-1}\right)$ & 0.047 & 15.8 \\
\hline $\mathrm{pH}$ & 6.3 & 7.6 \\
\hline $\mathrm{NH}_{4}-\mathrm{N}\left(\mathrm{g} \mathrm{kg}^{-1}\right)$ & 0.0005 & 2.9 \\
\hline Total $\mathrm{N}\left(\mathrm{g} \mathrm{kg}^{-1}\right)$ & 0.012 & 4.3 \\
\hline E. $\operatorname{coli}\left(\mathrm{CFU} \mathrm{mL} \mathrm{mL}^{-1}\right)$ & $\mathrm{ND}^{\mathrm{a}}$ & $2.6 \times 10^{4}$ \\
\hline Enterococcus sp. $\left(\mathrm{CFU} \mathrm{mL} \mathrm{m}^{-1}\right)$ & ND & $3.2 \times 10^{4}$ \\
\hline $\operatorname{TOC}^{\mathrm{a}}(\%)$ & 2 & 1.15 \\
\hline $\mathrm{K}^{\mathrm{a}}\left(\mathrm{mm} \mathrm{h}^{-1}\right)$ & 61.1 & NA \\
\hline
\end{tabular}

$538{ }^{\mathrm{a}} \mathrm{ND}$ indicates not detected, NA not applicable, EC electrical conductivity, TOC total organic 539 carbon, and K hydraulic conductivity.

540

541

542 
544 Average ( \pm standard deviation) percentage leached, retained, and recovered, of total applied

545 mineral N, phage, E. coli, and Enterococcus spp. for different treatments. Means within a

546 constituent and single column that are followed by different letters are significantly different

547 at $P<0.05$.

548

\begin{tabular}{lllll}
\hline Constituents & Soil & Leached (\%) & Retained (\%) & Recovery (\%) \\
& & & & \\
Mineral N & Intact & $22 \pm 2 \mathrm{a}$ & $59 \pm 5 \mathrm{a}$ & $81 \pm 6$ \\
& Disturbed & $17 \pm 1 \mathrm{~b}$ & $69 \pm 4 \mathrm{~b}$ & $86 \pm 3$ \\
& Intact & $15.9 \pm 8.4$ & $3.1 \pm 1.3$ & $19 \pm 8.4$ \\
Phage & Disturbed & $9.3 \pm 3.6$ & $4.7 \pm 2.3$ & $14 \pm 4.7$ \\
& Intact & $0.61 \pm 0.34$ & $11.4 \pm 9.5 \mathrm{a}$ & $12 \pm 9.3 \mathrm{a}$ \\
E. coli & Disturbed & $0.82 \pm 0.10$ & $60.2 \pm 3.5 \mathrm{~b}$ & $61 \pm 3.5 \mathrm{~b}$ \\
& Intact & $0.17 \pm 0.17$ & $17.0 \pm 11.0$ & $17.2 \pm 10.9$ \\
Ent. spp. & Disturbed & $0.12 \pm 0.01$ & $15.3 \pm 1.1$ & $15.4 \pm 1.1$ \\
& & & &
\end{tabular}

549

550 
551 Fig. 1. Setup of the leaching experiment (S1, slurry slit; S2 and S3, surrounding

552 soil; and S4, bottom section of the column).

553

554 Fig. 2. Within-soil measurements of $\mathrm{pH}$, electrical conductivity (EC), volatile solids (VS),

555 soil water content ( $\mathrm{SWC}), \mathrm{NH}_{4}-\mathrm{N}, \mathrm{NO}_{3}-\mathrm{N}$, Phage, E. coli, and Enterococcus species, taken at

556 different soil positions (S1, slurry slit; S2 and S3, surrounding soil; and S4, bottom section of

557 the column) of the intact and disturbed soil columns one week after the final irrigation event.

558 The error bars are the standard error.

559

560 Fig. 3. Leachate measurements of total organic carbon (TOC), FBA (a conservative tracer),

$561 \mathrm{NH}_{4}-\mathrm{N}, \mathrm{NO}_{3}-\mathrm{N}$, estrogen, phage, E. coli, Enterococcus species, $\mathrm{pH}$, electrical conductivity

562 (EC), and turbidity during each of the four irrigation events, for both intact and disturbed soil

563 conditions. The error bars are the standard error.

564

565

566

567 


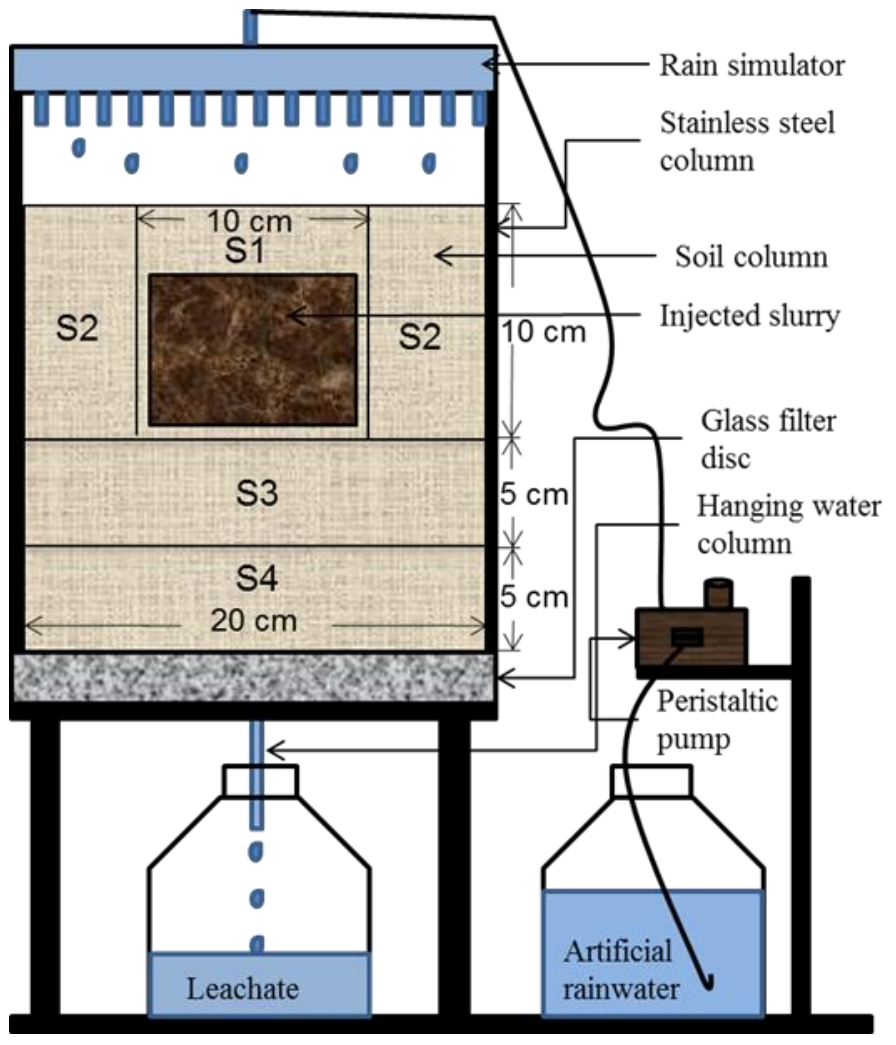



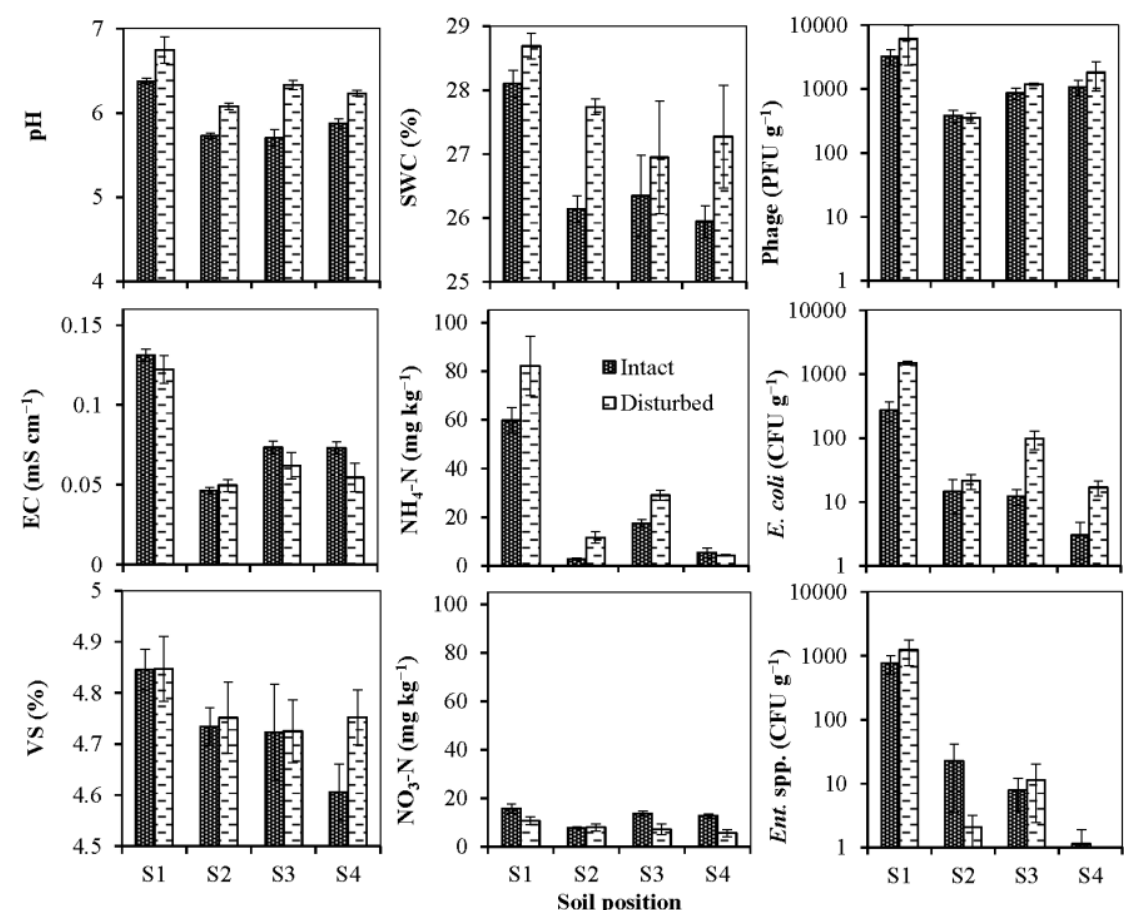

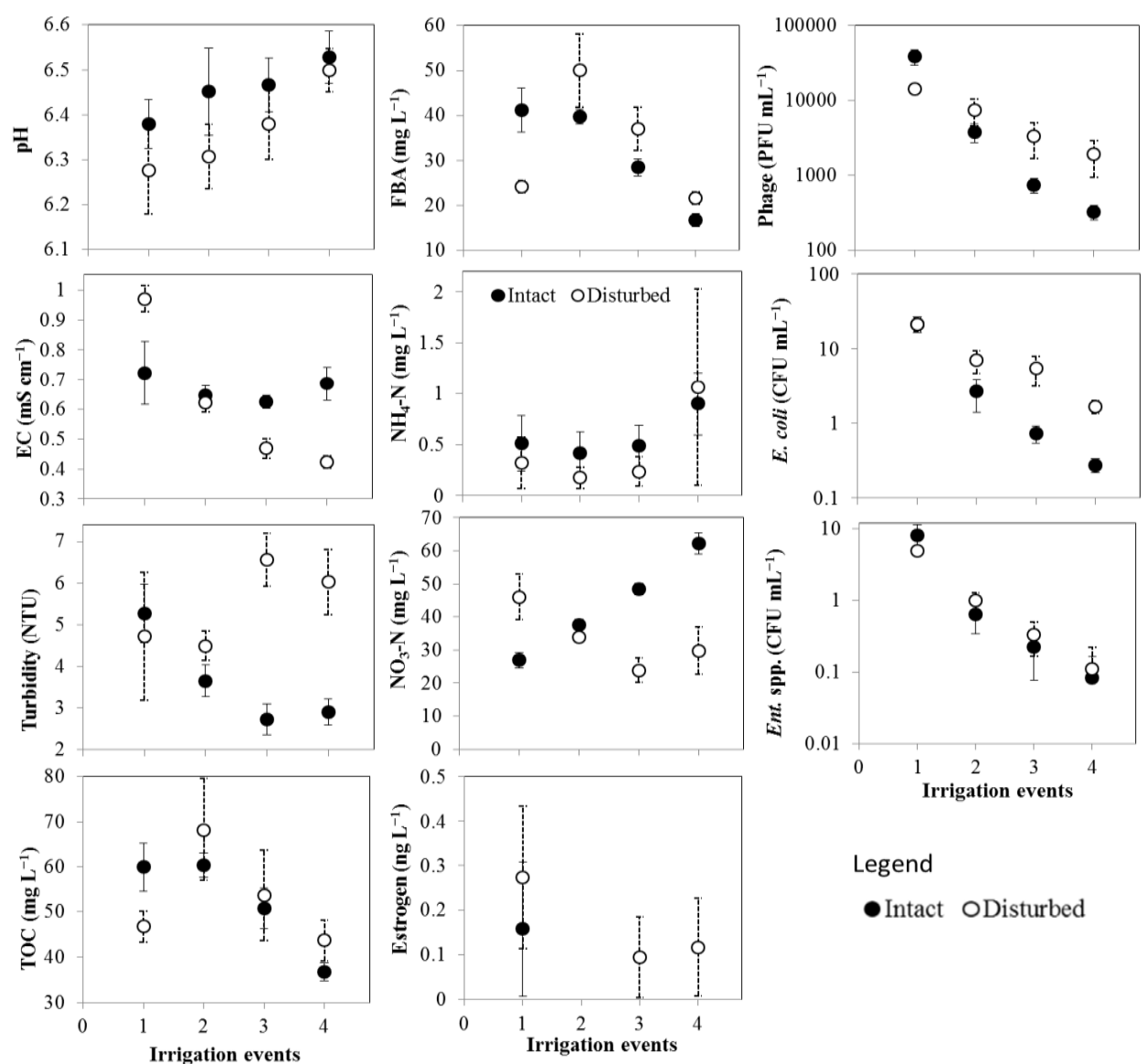